Bull. Chem. Soc. Ethiop. 2003, 17(1), 27-34.

ISSN 1011-3924

Printed in Ethiopia

(c) 2003 Chemical Society of Ethiopia

\title{
SPECTROSCOPIC STUDIES OF SOME LANTHANIDE(III) NITRATE COMPLEXES SYNTHESIZED FROM A NEW LIGAND 2,6-BIS-(SALICYLALDEHYDE HYDRAZONE)-4-CHLOROPHENOL
}

\author{
M. Gaye ${ }^{*}$, F.B. Tamboura, A.S. Sall \\ Université Cheikh Anta Diop, Faculté des Sciences et Techniques, Département de Chimie, \\ Dakar, Sénégal
}

(Received July 17, 2002; revised November 1, 2002)

\begin{abstract}
The ligand 2,6-bis-(salicylaldehydehydrazone)-4-chlorophenol $\left(\mathrm{H}_{5} \mathrm{~L}\right)$ and its binuclear lanthanide(III) nitrate complexes $\left\{\left[\mathrm{Ln}_{2}\left(\mathrm{H}_{4} \mathrm{~L}\right)_{3}\left(\mathrm{NO}_{3}\right)\right]\left(\mathrm{NO}_{3}\right)_{2} \cdot \mathrm{mH}_{2} \mathrm{O}\right\}$ where $\mathrm{Ln}=\mathrm{La}, \mathrm{Ce}, \mathrm{Pr}, \mathrm{Nd}, \mathrm{Sm}$, Gd, Dy, Er, Yb and Y, have been synthesized. The complexes were characterized by chemical analysis, conductance, magnetic moment measurements and infrared spectra. Infrared study indicates that the ligand behaves both as neutral and ionic $\mathrm{O}$ donors and as neutral $\mathrm{N}$ donors.
\end{abstract}

KEY WORDS: Lanthanide(III) complexes, Schiff base, 2,6-bis-(Salicylaldehydehydrazone)-4chlorophenol, Infrared spectra, Molar conductivities, Magnetic moment

\section{INTRODUCTION}

The use of trivalent lanthanide ions and those metal and related (e.g. Y(III)) to control reactions involving the formation of imines groups is well known. The reaction is widely used to synthesize lanthanide complexes from macrocyclic [1-3] and macroacyclic [4-6] ligands. These complexes have been extensively studied in the past decade. They are used as catalysts [7] in transesterification, as radiopharmaceuticals [8] and as fluoroimmuno assay reagents [9, 10]. Certain $\mathrm{Eu}(\mathrm{III})$ and $\mathrm{Nd}(\mathrm{III})$ complexes have been reported to set as lasers [3]. In this work we describe the preparation of the ligand 2,6-bis-(salicylaldehydehydrazone)-4-chlorophenol $\left(\mathrm{H}_{5} \mathrm{~L}\right.$ ). This phenol-based macroacyclic ligand have two similar metal-binding sites sharing the phenolic oxygen atom. Due to the flexibility of the arms it was able to adjust its cavity to match the sized metal ions.

Two methods for the preparation of complexes containing macrocyclic ligands have been reported in the literature. The first method involves condensation of keto precursors with polyamines by the template method $[11,12]$ and in the second method, the ligand is first synthesized and isolated and the metal ion added to prepare the complexes [13, 14]. In our previous research on transition metal complexes we have used both routes [15-18]. Herein we report the reaction of $\mathrm{H}_{5} \mathrm{~L}$ with a range of $\mathrm{Ln}(\mathrm{Ln}=\mathrm{La}, \mathrm{Ce}, \mathrm{Pr}, \mathrm{Nd}, \mathrm{Sm}, \mathrm{Gd}, \mathrm{Dy}, \mathrm{Er}, \mathrm{Yb}$ and $\mathrm{Y})$ to give $\left\{\left[\mathrm{Ln}_{2}\left(\mathrm{H}_{4} \mathrm{~L}\right)_{3}\left(\mathrm{NO}_{3}\right)\right]\left(\mathrm{NO}_{3}\right)_{2} \cdot \mathrm{mH}_{2} \mathrm{O}\right\}$. It's to be noted that $\mathrm{H}_{5} \mathrm{~L}$ terminology is used to indicate that the ligand has five potentially replaceable protons. In the reaction only one $\mathrm{H}$ atom is replaced (the o-chlorophenol proton) to give an $\mathrm{H}_{4} \mathrm{~L}$ ligand. The characterization of these new lanthanides complexes is also described.

*Corresponding author. E-mail: mlgayeastou@yahoo.fr 


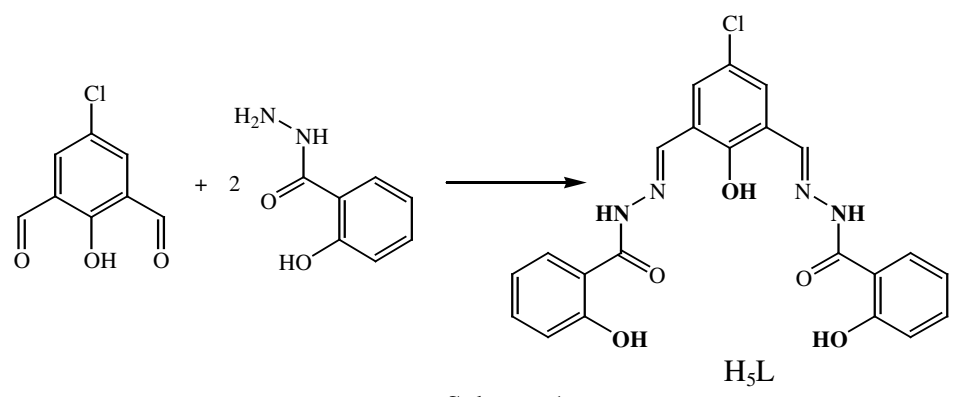

Scheme 1

\section{EXPERIMENTAL}

\section{Reagents}

The $\mathrm{Ln}\left(\mathrm{NO}_{3}\right)_{3} \cdot \mathrm{mH}_{2} \mathrm{O}$ complexes was obtained from Aldrich and was used without purification. The salicylaldehydehydrazide, ethanol and methanol were obtained from Jansen and were used without further purification. The 2,6-diformyl-4-chlorophenol was synthesized using an improvement on the method described in the literature by recrystallizing the compound in $n$ hexane/chloroform [16].

Magnetic measurement was carried out at room temperature with a Gouy balance and $\mathrm{CuSO}_{4}$ was used as a calibrant. Infrared spectra of the compounds were recorded on a Perking Elmer 580 B FTIR spectrophotometer as Nujol mulls using $\mathrm{CsF}$ windows or $\mathrm{KBr}$ pellets in the range 4000-400 $\mathrm{cm}^{-1}$. Electronic spectra were recorded on a Jasco spectrophotometer. Elemental analyses were obtained from the Microanalytical Service of the University of Padova (Italy).

Synthesis of 2,6-bis(salicylaldehydehydrazone)-4-chlorophenol $\left(H_{5} L\right)$. 2,6-diformyl-4-chlorophenol (2 g, $10.8 \mathrm{mmol})$ and salicylaldehydehydrazide $(3.3 \mathrm{~g}, 21.7 \mathrm{mmol})$ were dissolved in 30 $\mathrm{mL}$ of ethanol and two drops of glacial acetic acid were added. The mixture was then refluxed for two hours. Upon cooling, a yellowish precipitate was obtained. The product was isolated by filtration, washed with $2 \times 10 \mathrm{~mL}$ of ether and dried at room temperature over $\mathrm{P}_{4} \mathrm{O}_{10}$. The yield was $83 \%$ and the melting point is $>230{ }^{\circ} \mathrm{C}$.

\section{Synthesis of complexes}

$\left\{\left[\mathrm{La}_{2}\left(\mathrm{H}_{4} \mathrm{~L}\right)_{3}\left(\mathrm{NO}_{3}\right)\right]\left(\mathrm{NO}_{3}\right)_{2} \cdot 6 \mathrm{H}_{2} \mathrm{O}\right\}$. The ligand $\mathrm{H}_{5} \mathrm{~L}(0.2 \mathrm{~g}, 0.409 \mathrm{mmol})$ was suspended in $20 \mathrm{~mL}$ of methanol. Lanthanum(III) nitrate hexahydrate $(0.15 \mathrm{~g}, 0.416 \mathrm{mmol})$ was dissolved in $10 \mathrm{~mL}$ of methanol and the solution obtained was added to the previous suspension. The mixture was stirred and refluxed for one hour. Upon cooling the yellow precipitate obtained was filtered off and washed with $2 \times 20 \mathrm{~mL}$ of $\mathrm{Et}_{2} \mathrm{O}$. The compound was dried at room temperature over $\mathrm{P}_{4} \mathrm{O}_{10}$. Yield $65 \%$.

$\left\{\left[\mathrm{Ce}_{2}\left(\mathrm{H}_{4} \mathrm{~L}\right)_{3}\left(\mathrm{NO}_{3}\right)\right]\left(\mathrm{NO}_{3}\right)_{2} \cdot 7 \mathrm{H}_{2} \mathrm{O}\right\}$. The procedure for $\left\{\left[\mathrm{La}_{2}\left(\mathrm{H}_{4} \mathrm{~L}\right)_{3}\left(\mathrm{NO}_{3}\right)\right]\left(\mathrm{NO}_{3}\right)_{2} \cdot 6 \mathrm{H}_{2} \mathrm{O}\right\}$ was repeated and $\mathrm{Ce}\left(\mathrm{NO}_{3}\right)_{3} \cdot 6 \mathrm{H}_{2} \mathrm{O}(0.1917 \mathrm{~g}, 0.416 \mathrm{mmol})$ was used instead of $\mathrm{La}\left(\mathrm{NO}_{3}\right)_{3} \cdot 6 \mathrm{H}_{2} \mathrm{O}$. A yellow precipitate was obtained washed with $\mathrm{Et}_{2} \mathrm{O}$ and dried over $\mathrm{P}_{4} \mathrm{O}_{10}$. Yield $60 \%$.

$\left\{\left[\mathrm{Gd}_{2}\left(\mathrm{H}_{4} \mathrm{~L}\right)_{3}\left(\mathrm{NO}_{3}\right)\right]\left(\mathrm{NO}_{3}\right)_{2} \cdot 6 \mathrm{H}_{2} \mathrm{O}\right\}$. The ligand $\mathrm{H}_{5} \mathrm{~L}(0.1 \mathrm{~g}, 0.2045 \mathrm{mmol})$ was suspended in $10 \mathrm{~mL}$ of methanol and $\mathrm{LiOH} . \mathrm{H}_{2} \mathrm{O}(0.019 \mathrm{~g}, 0.452 \mathrm{mmol})$ was added. An orange precipitate was 
formed. A solution of gadolinium(III) nitrate hexahydrate $(0.1028 \mathrm{~g}, 0.2228 \mathrm{mmol})$ in $15 \mathrm{~mL}$ of methanol was added. The mixture was then refluxed for one hour. After cooling the precipitate was isolated by filtration. The yellow solid was washed with $2 \times 20 \mathrm{~mL}$ of ether and dried over $\mathrm{P}_{4} \mathrm{O}_{10}$. Yield $70 \%$.

$\left\{\left[\mathrm{Nd}_{2}\left(\mathrm{H}_{4} \mathrm{~L}\right)_{3}\left(\mathrm{NO}_{3}\right)\right]\left(\mathrm{NO}_{3}\right)_{2} \cdot 5 \mathrm{H}_{2} \mathrm{O}\right\}$. The procedure for $\left\{\left[\mathrm{Gd}_{2}\left(\mathrm{H}_{4} \mathrm{~L}\right)_{3}\left(\mathrm{NO}_{3}\right)\right]\left(\mathrm{NO}_{3}\right)_{2} \cdot 6 \mathrm{H}_{2} \mathrm{O}\right\}$ was repeated and $\mathrm{Nd}\left(\mathrm{NO}_{3}\right)_{3} \cdot 6 \mathrm{H}_{2} \mathrm{O}(0.0977 \mathrm{~g}, 0.2228 \mathrm{mmol})$ was used instead of $\mathrm{Gd}\left(\mathrm{NO}_{3}\right)_{3} \cdot 6 \mathrm{H}_{2} \mathrm{O}$. A yellow precipitate was obtained washed with $\mathrm{Et}_{2} \mathrm{O}$ and dried over $\mathrm{P}_{4} \mathrm{O}_{10}$. Yield $63 \%$.

$\left\{\left[\mathrm{Sm}_{2}\left(\mathrm{H}_{4} \mathrm{~L}\right)_{3}\left(\mathrm{NO}_{3}\right)\right]\left(\mathrm{NO}_{3}\right)_{2} \cdot 4 \mathrm{H}_{2} \mathrm{O}\right\}$. The procedure for $\left\{\left[\mathrm{Gd}_{2}\left(\mathrm{H}_{4} \mathrm{~L}\right)_{3}\left(\mathrm{NO}_{3}\right)\right]\left(\mathrm{NO}_{3}\right)_{2} \cdot 6 \mathrm{H}_{2} \mathrm{O}\right\}$ was repeated and $\mathrm{Sm}\left(\mathrm{NO}_{3}\right)_{3} \cdot 6 \mathrm{H}_{2} \mathrm{O}(0.0991 \mathrm{~g}, 0.2228 \mathrm{mmol})$ was used instead of $\mathrm{Gd}\left(\mathrm{NO}_{3}\right)_{3} \cdot 6 \mathrm{H}_{2} \mathrm{O}$. A yellow precipitate was obtained washed with $\mathrm{Et}_{2} \mathrm{O}$ and dried over $\mathrm{P}_{4} \mathrm{O}_{10}$. Yield 55\%.

$\left\{\left[\mathrm{Y}_{2}\left(\mathrm{H}_{4} \mathrm{~L}\right)_{3}\left(\mathrm{NO}_{3}\right)\right]\left(\mathrm{NO}_{3}\right)_{2} \cdot 2 \mathrm{H}_{2} \mathrm{O}\right\}$. To $\mathrm{H}_{5} \mathrm{~L}(0.1 \mathrm{~g}, 0.2045 \mathrm{mmol})$ in $20 \mathrm{~mL}$ of methanol, was added LiOH. $\mathrm{H}_{2} \mathrm{O}(0.019 \mathrm{~g}, 0.452 \mathrm{mmol})$. To the orange solution obtained was added $\mathrm{Y}\left(\mathrm{NO}_{3}\right)_{3} \cdot 6 \mathrm{H}_{2} \mathrm{O}$ $(0.0783 \mathrm{~g} ; 0.2045 \mathrm{mmol})$. A yellow precipitate was formed immediately. The mixture was refluxed for one hour. Upon cooling the product was filtered off and washed with $2 \times 15 \mathrm{~mL}$ of $\mathrm{MeOH}$ and $2 \times 15 \mathrm{~mL}$ of $\mathrm{Et}_{2} \mathrm{O}$ before being dried over $\mathrm{P}_{4} \mathrm{O}_{10}$. Yield $75 \%$.

$\left\{\left[\mathrm{Dy} y_{2}\left(\mathrm{H}_{4} \mathrm{~L}\right)_{3}\left(\mathrm{NO}_{3}\right)\right]\left(\mathrm{NO}_{3}\right)_{2} \cdot 5 \mathrm{H}_{2} \mathrm{O}\right\}$. The procedure for $\left\{\left[\mathrm{Gd}_{2}\left(\mathrm{H}_{4} \mathrm{~L}\right)_{3}\left(\mathrm{NO}_{3}\right)\right]\left(\mathrm{NO}_{3}\right)_{2} \cdot 6 \mathrm{H}_{2} \mathrm{O}\right\}$ was repeated and $\mathrm{Dy}\left(\mathrm{NO}_{3}\right)_{3} \cdot 6 \mathrm{H}_{2} \mathrm{O}(0.1017 \mathrm{~g}, 0.2228 \mathrm{mmol})$ was used instead of $\mathrm{Gd}\left(\mathrm{NO}_{3}\right)_{3} \cdot 6 \mathrm{H}_{2} \mathrm{O}$. A yellow precipitate was obtained washed with $\mathrm{Et}_{2} \mathrm{O}$ and dried over $\mathrm{P}_{4} \mathrm{O}_{10}$. Yield $49 \%$.

$\left\{\left[\mathrm{Er}_{2}\left(\mathrm{H}_{4} \mathrm{~L}\right)_{3}\left(\mathrm{NO}_{3}\right)\right]\left(\mathrm{NO}_{3}\right)_{2} \cdot 4 \mathrm{H}_{2} \mathrm{O}\right\}$. The procedure for $\left\{\left[\mathrm{Gd}_{2}\left(\mathrm{H}_{4} \mathrm{~L}\right)_{3}\left(\mathrm{NO}_{3}\right)\right]\left(\mathrm{NO}_{3}\right)_{2} \cdot 6 \mathrm{H}_{2} \mathrm{O}\right\}$ was repeated and $\mathrm{Er}\left(\mathrm{NO}_{3}\right)_{3} \cdot 6 \mathrm{H}_{2} \mathrm{O}(0.1028 \mathrm{~g}, 0.2228 \mathrm{mmol})$ was used instead of $\mathrm{Gd}\left(\mathrm{NO}_{3}\right)_{3} \cdot 6 \mathrm{H}_{2} \mathrm{O}$. A yellow precipitate was obtained washed with $\mathrm{Et}_{2} \mathrm{O}$ and dried over $\mathrm{P}_{4} \mathrm{O}_{10}$. Yield 53\%.

$\left\{\left[\mathrm{Pr}_{2}\left(\mathrm{H}_{4} \mathrm{~L}\right)_{3}\left(\mathrm{NO}_{3}\right)\right]\left(\mathrm{NO}_{3}\right)_{2} \cdot 5 \mathrm{H}_{2} \mathrm{O}\right\}$. The procedure for $\left\{\left[\mathrm{Gd}_{2}\left(\mathrm{H}_{4} \mathrm{~L}\right)_{3}\left(\mathrm{NO}_{3}\right)\right]\left(\mathrm{NO}_{3}\right)_{2} \cdot 6 \mathrm{H}_{2} \mathrm{O}\right\}$ was repeated and $\operatorname{Pr}\left(\mathrm{NO}_{3}\right)_{3} .6 \mathrm{H}_{2} \mathrm{O}(0.0969 \mathrm{~g}, 0.2228 \mathrm{mmol})$ was used instead of $\mathrm{Gd}\left(\mathrm{NO}_{3}\right)_{3} \cdot 6 \mathrm{H}_{2} \mathrm{O}$. A yellow precipitate was obtained washed with $\mathrm{Et}_{2} \mathrm{O}$ and dried over $\mathrm{P}_{4} \mathrm{O}_{10}$. Yield $55 \%$.

$\left\{\left[\mathrm{Yb}_{2}\left(\mathrm{H}_{4} \mathrm{~L}\right)_{3}\left(\mathrm{NO}_{3}\right)\right]\left(\mathrm{NO}_{3}\right)_{2} \cdot 4 \mathrm{H}_{2} \mathrm{O}\right\}$. The procedure for $\left\{\left[\mathrm{Gd}_{2}\left(\mathrm{H}_{4} \mathrm{~L}\right)_{3}\left(\mathrm{NO}_{3}\right)\right]\left(\mathrm{NO}_{3}\right)_{2} \cdot 6 \mathrm{H}_{2} \mathrm{O}\right\}$ was repeated and $\mathrm{Yb}\left(\mathrm{NO}_{3}\right)_{3} \cdot 6 \mathrm{H}_{2} \mathrm{O}(0.1041 \mathrm{~g}, 0.2228 \mathrm{mmol})$ was used instead of $\mathrm{Gd}\left(\mathrm{NO}_{3}\right)_{3} \cdot 6 \mathrm{H}_{2} \mathrm{O}$. A yellow precipitate was obtained washed with $\mathrm{Et}_{2} \mathrm{O}$ and dried over $\mathrm{P}_{4} \mathrm{O}_{10}$. Yield $69 \%$.

\section{RESULTS AND DISCUSSIONS}

We have found that the reaction between 2,6-diformyl-4-chlorophenol and salicylaldehyde hydrazide in ethanol gives a yellow identifiable solid. From this ligand $\left(\mathrm{H}_{5} \mathrm{~L}\right)$ we have prepared complexes using hydrated lanthanide nitrates. The presence of the $-\mathrm{Cl}$ group in the para position of phenol moiety promote the reaction of the Schiff base as monoanionic ligand and the formation of the binuclear complexes containing three monoanionic Schiff base and three nitrate groups. The general composition of all the complexes correspond to $\left\{\left[\mathrm{Ln}_{2}\left(\mathrm{H}_{4} \mathrm{~L}\right)_{3}\left(\mathrm{NO}_{3}\right)\right]\left(\mathrm{NO}_{3}\right)_{2} \cdot \mathrm{nH}_{2} \mathrm{O}\right\}$ where $\mathrm{Ln}=\mathrm{La}, \mathrm{Ce}, \mathrm{Pr}, \mathrm{Nd}, \mathrm{Sm}, \mathrm{Gd}, \mathrm{Dy}, \mathrm{Er}, \mathrm{Yb}$ and Y. The compounds were purified in suitable solvents and analytically pure material was obtained. The analytical data of the ligand and the complexes are summarized in Table 1. The complexes are air-stable and non-hygroscopic and could be stored at room temperature without alteration. The products have poor solubility in common organic solvents. 
Table 1. Analytical data for the ligand and the complexes of the ligand.

\begin{tabular}{|l|l|l|l|l|}
\hline \multirow{2}{*}{ Compounds } & \multicolumn{3}{|c|}{ Found (calc.) \% } & \multirow{2}{*}{ Colour } \\
\cline { 2 - 5 } & \multicolumn{1}{|c|}{$\mathrm{C}$} & \multicolumn{1}{|c|}{$\mathrm{H}$} & $\mathrm{N}$ & \\
\hline $\mathrm{C}_{22} \mathrm{H}_{17} \mathrm{~N}_{4} \mathrm{O}_{5} \mathrm{Cl} .2 \mathrm{H}_{2} \mathrm{O}$ & $54.36(54.05)$ & $4.58(4.33)$ & $11.25(11.46)$ & Yellowish \\
\hline$\left\{\left[\mathrm{La}_{2}\left(\mathrm{H}_{4} \mathrm{~L}\right)_{3}\left(\mathrm{NO}_{3}\right)\right]\left(\mathrm{NO}_{3}\right)_{2} \cdot 6 \mathrm{H}_{2} \mathrm{O}\right\}$ & $41.11(41.12)$ & $2.96(3.13)$ & $11.13(10.90)$ & Yellow \\
\hline$\left\{\left[\mathrm{Ce}_{2}\left(\mathrm{H}_{4} \mathrm{~L}\right)_{3}\left(\mathrm{NO}_{3}\right)\right]\left(\mathrm{NO}_{3}\right)_{2} .7 \mathrm{H}_{2} \mathrm{O}\right\}$ & $40.54(40.69)$ & $2.87(3.21)$ & $10.91(10.78)$ & Yellow \\
\hline$\left\{\left[\mathrm{Pr}_{2}\left(\mathrm{H}_{4} \mathrm{~L}\right)_{3}\left(\mathrm{NO}_{3}\right)\right]\left(\mathrm{NO}_{3}\right)_{2} .5 \mathrm{H}_{2} \mathrm{O}\right\}$ & $41.33(41.43)$ & $3.18(3.06)$ & $10.67(10.98)$ & Yellow \\
\hline$\left\{\left[\mathrm{Nd}_{2}\left(\mathrm{H}_{4} \mathrm{~L}\right)_{3}\left(\mathrm{NO}_{3}\right)\right]\left(\mathrm{NO}_{3}\right)_{2} .5 \mathrm{H}_{2} \mathrm{O}\right\}$ & $41.16(41.28)$ & $2.99(3.04)$ & $10.69(10.94)$ & Yellow \\
\hline$\left\{\left[\mathrm{Sm}_{2}\left(\mathrm{H}_{4} \mathrm{~L}\right)_{3}\left(\mathrm{NO}_{3}\right)\right]\left(\mathrm{NO}_{3}\right)_{2} .4 \mathrm{H}_{2} \mathrm{O}\right\}$ & $41.22(41.67)$ & $3.01(2.97)$ & $10.86(11.05)$ & Yellow \\
\hline$\left\{\left[\mathrm{Gd}_{2}\left(\mathrm{H}_{4} \mathrm{~L}\right)_{3}\left(\mathrm{NO}_{3}\right)\right]\left(\mathrm{NO}_{3}\right)_{2} \cdot 6 \mathrm{H}_{2} \mathrm{O}\right\}$ & $39.98(40.36)$ & $3.09(3.15)$ & $10.56(10.70)$ & Yellow \\
\hline$\left\{\left[\mathrm{Dy}_{2}\left(\mathrm{H}_{4} \mathrm{~L}\right)_{3}\left(\mathrm{NO}_{3}\right)\right]\left(\mathrm{NO}_{3}\right)_{2} .5 \mathrm{H}_{2} \mathrm{O}\right\}$ & $40.16(40.51)$ & $3.09(2.99)$ & $10.50(10.74)$ & Yellow \\
\hline$\left\{\left[\mathrm{Er}_{2}\left(\mathrm{H}_{4} \mathrm{~L}\right)_{3}\left(\mathrm{NO}_{3}\right)\right]\left(\mathrm{NO}_{3}\right)_{2} .4 \mathrm{H}_{2} \mathrm{O}\right\}$ & $39.99(40.69)$ & $3.09(2.90)$ & $10.45(10.78)$ & Yellow \\
\hline$\left\{\left[\mathrm{Yb}_{2}\left(\mathrm{H}_{4} \mathrm{~L}\right)_{3}\left(\mathrm{NO}_{3}\right)\right]\left(\mathrm{NO}_{3}\right)_{2} .4 \mathrm{H}_{2} \mathrm{O}\right\}$ & $39.93(40.45)$ & $2.80(2.88)$ & $10.53(10.72)$ & Yellow \\
\hline$\left\{\left[\mathrm{Y}_{2}\left(\mathrm{H}_{4} \mathrm{~L}\right)_{3}\left(\mathrm{NO}_{3}\right)\right]\left(\mathrm{NO}_{3}\right)_{2} .2 \mathrm{H}_{2} \mathrm{O}\right\}$ & $45.02(45.06)$ & $2.88(2.99)$ & $11.33(11.97)$ & Yellow \\
\hline
\end{tabular}

Infrared spectra. The ligand is expected to be heptadentate, the possible coordination sites being phenol-oxygen (three), azomethine nitrogen (two) and the amide groups (two). Comparison of the infrared spectra of the ligand and the complexes suggests that the ligand is pentadentate with ligand coordinating to the metal through the two carbonyl-oxygen, the one 4-chlorophenol oxygen and two azomethine sites.

The infrared spectrum of the ligand was devoid of absorptions characteristic of an $\mathrm{NH}_{2}$ function. A strong band at $c a .1635 \mathrm{~cm}^{-1}$ is assigned to the $v(\mathrm{C}=\mathrm{O})$ vibration. The band due to the $v(\mathrm{C}=\mathrm{N})$ vibration is observed at $1614 \mathrm{~cm}^{-1}$ as a strong band. The $\mathrm{N}-\mathrm{H}$ stretching vibrations occur at 3290 and $3220 \mathrm{~cm}^{-1}$. The broad band of medium intensity occurring in the range 3500$3400 \mathrm{~cm}^{-1}$ is due to the $\mathrm{O}-\mathrm{H}$ stretching vibration of the phenolic $\mathrm{OH}$ groups.

Upon coordination, the band due to the $\mathrm{N}-\mathrm{H}$ stretching vibrations in the free ligand remains unaffected precluding the possibility of coordination through the amide oxygen in his amide form.

A considerable lowering of the $v(\mathrm{C}=\mathrm{O})$ frequency is observed in the spectra of all the complexes, indicating a decrease in the stretching force constant of the $\mathrm{C}=\mathrm{O}$ bond as a consequence of the coordination of the oxygen atom to the metal ion. This band appears at $c a$. $1615 \mathrm{~cm}^{-1}$.

The important band at $1614 \mathrm{~cm}^{-1}$ in the free ligand attributed to $\mathrm{v}(\mathrm{C}=\mathrm{N})$, is shifted to lower frequencies and appears in the region $1595-1520 \mathrm{~cm}^{-1}$ in the spectra of all the complexes. This fact suggests the involvement of the nitrogen atom of the azomethine moiety in the coordination of the ligand to the metal ion.

The bands at $3500-3400 \mathrm{~cm}^{-1}$ are affected by metal coordination. The interpretation of these bands due to the $v(\mathrm{OH})$ of the phenolic groups is frustrated by the presence of three phenolic groups in the ligand. The broad band of medium intensity occurring in $3300-3400 \mathrm{~cm}^{-1}$ region is due to the symmetric and the antisymmetric O-H stretching vibrations of the lattice water [19]. No characteristic band of coordinated water molecules was observed. In the region 410-480 $\mathrm{cm}^{-1}$ a medium-intensity band characteristic of a $\mathrm{v}(\mathrm{Ln}-\mathrm{O})$ vibration of the phenolic oxygen was observed [20]. Bands in the far infrared spectra, in the region $280-240 \mathrm{~cm}^{-1}$ can be assigned to $v(\mathrm{Ln}-\mathrm{N})$ vibration in the new complexes [20].

From the infrared spectra of the nitrato complexes, information regarding the possible bonding modes of the nitrate group was obtained. The bands at $c a .1468-1440 \mathrm{~cm}^{-1}$ and 1320 $1300 \mathrm{~cm}^{-1}$ are due respectively to $\mathrm{v}(\mathrm{N}=\mathrm{O}) .(\mathrm{v} 1)$ and $\mathrm{v}_{\mathrm{as}}\left(\mathrm{NO}_{2}\right)(\mathrm{v} 5)$ of the coordinated nitrate. The $\mathrm{v}_{\mathrm{s}}\left(\mathrm{NO}_{2}\right)(\mathrm{v} 2)$ is detected at $c a .1040-1030 \mathrm{~cm}^{-1}$. These facts are characteristic of bidentate 
chelating nitrate $[19,21]$. The separation $\Delta v=v 1-v 5$ has been used as criterion of differentiation between mono and bidentate chelating nitrates, with $\Delta v$ increasing as the coordination changes from mono to bidentate and/or bridging modes. The magnitude of this separation for these complexes (Table 2) is indicative of a bidentate nitrate [22]. The strong and sharp band at 1380 $\mathrm{cm}^{-1}$ is characteristic of ionic nitrate. In summary, these nitrato complexes contains both coordinated and ionic nitrates.

Table 2. Infrared data of the ligand and the lanthanides complexes of the ligand.

\begin{tabular}{|c|c|c|c|c|c|c|c|c|c|}
\hline \multicolumn{4}{|c|}{ Macroacyclic ligand } & \multicolumn{4}{|c|}{$\begin{array}{l}\text { Exocyclic ligand } \\
\text { bidentate nitrate }\end{array}$} & \multirow{2}{*}{\begin{tabular}{|c|}
$\begin{array}{l}\text { Ionic } \\
\text { nitrate }\end{array}$ \\
$v$ \\
$(\mathrm{~N}=\mathrm{O})$ \\
$(\mathrm{v} 3)$
\end{tabular}} & \multirow{2}{*}{\begin{tabular}{|l}
$\begin{array}{l}\text { Lattice } \\
\text { water }\end{array}$ \\
$v(\mathrm{O}-\mathrm{H})$
\end{tabular}} \\
\hline Compounds & $v(\mathrm{C}-\mathrm{H})$ & $v(\mathrm{C}=\mathrm{O})$ & $v(\mathrm{C}=\mathrm{N})$ & $\begin{array}{c}\mathrm{v} \\
(\mathrm{N}=\mathrm{O}) \\
(\mathrm{v} 1) \\
\end{array}$ & $\begin{array}{c}v_{\text {asym }} \\
\left(\mathrm{NO}_{2}\right) \\
(\mathrm{v} 5)\end{array}$ & \begin{tabular}{|c}
$v_{\text {sym }}$ \\
$\left(\mathrm{NO}_{2}\right)$ \\
$(\mathrm{v} 2)$ \\
\end{tabular} & $\Delta \mathrm{v}^{*}$ & & \\
\hline $\mathrm{C}_{22} \mathrm{H}_{16} \mathrm{~N}_{4} \mathrm{O}_{5} \mathrm{Cl} .2 \mathrm{H}_{2} \mathrm{O}$ & 3000 & 1635 & 1614 & & & & & & \\
\hline$\left\{\left[\mathrm{La}_{2}\left(\mathrm{H}_{4} \mathrm{~L}\right)_{3}\left(\mathrm{NO}_{3}\right)\right]\left(\mathrm{NO}_{3}\right)_{2} \cdot 6 \mathrm{H}_{2} \mathrm{O}\right\}$ & 2920 & 1615 & 1595 & 1440 & 1320 & 1040 & 120 & 1380 & 3220 \\
\hline$\left\{\left[\mathrm{Ce}_{2}\left(\mathrm{H}_{4} \mathrm{~L}_{3}\left(\mathrm{NO}_{3}\right)\right]\left(\mathrm{NO}_{3}\right)_{2} .7 \mathrm{H}_{2} \mathrm{O}\right\}\right.$ & 2922 & 1615 & 1592 & 1440 & 1320 & 1037 & 120 & 1381 & 3220 \\
\hline$\left\{\left[\mathrm{Pr}_{2}\left(\mathrm{H}_{4} \mathrm{~L}\right)_{3}\left(\mathrm{NO}_{3}\right)\right]\left(\mathrm{NO}_{3}\right)_{2} .5 \mathrm{H}_{2} \mathrm{O}\right\}$ & 2930 & 1614 & 1558 & 1464 & 1315 & 1037 & 149 & 1377 & 3220 \\
\hline$\left\{\left[\mathrm{Nd}_{2}\left(\mathrm{H}_{4} \mathrm{~L}\right)_{3}\left(\mathrm{NO}_{3}\right)\right]\left(\mathrm{NO}_{3}\right)_{2} .5 \mathrm{H}_{2} \mathrm{O}\right\}$ & 2940 & 1614 & 1560 & 1435 & 1315 & 1037 & 120 & 1379 & 3200 \\
\hline$\left\{\left[\mathrm{Sm}_{2}\left(\mathrm{H}_{4} \mathrm{~L}\right)_{3}\left(\mathrm{NO}_{3}\right)\right]\left(\mathrm{NO}_{3}\right)_{2} \cdot 4 \mathrm{H}_{2} \mathrm{O}\right.$ & 2919 & 1612 & 1560 & 1466 & 1315 & 1035 & 151 & 1380 & 3220 \\
\hline$\left\{\left[\mathrm{Gd}_{2}\left(\mathrm{H}_{4} \mathrm{~L}\right)_{3}\left(\mathrm{NO}_{3}\right)\right]\left(\mathrm{NO}_{3}\right)_{2} \cdot 6 \mathrm{H}_{2} \mathrm{O}\right\}$ & 2945 & 1614 & 1558 & 1431 & 1315 & 1035 & 116 & 1378 & 3220 \\
\hline$\left\{\left[\mathrm{Dy}_{2}\left(\mathrm{H}_{4} \mathrm{~L}\right)_{3}\left(\mathrm{NO}_{3}\right)\right]\left(\mathrm{NO}_{3}\right)_{2} .5 \mathrm{H}_{2} \mathrm{O}\right\}$ & 2918 & 1616 & 1558 & 1433 & 1315 & 1035 & 118 & 1375 & 3200 \\
\hline$\left\{\left[\mathrm{Er}_{2}\left(\mathrm{H}_{4} \mathrm{~L}\right)_{3}\left(\mathrm{NO}_{3}\right)\right]\left(\mathrm{NO}_{3}\right)_{2} \cdot 4 \mathrm{H}_{2} \mathrm{O}\right\}$ & 2940 & 1616 & 1523 & 1469 & 1310 & 1043 & 159 & 1375 & 3200 \\
\hline$\left\{\left[\mathrm{Yb}_{2}\left(\mathrm{H}_{4} \mathrm{~L}\right)_{3}\left(\mathrm{NO}_{3}\right)\right]\left(\mathrm{NO}_{3}\right)_{2} \cdot 4 \mathrm{H}_{2} \mathrm{O}\right\}$ & 2935 & 1616 & 1558 & 1469 & 1315 & 1035 & 154 & 1377 & 3200 \\
\hline$\left\{\left[\mathrm{Y}_{2}\left(\mathrm{H}_{4} \mathrm{~L}\right)_{3}\left(\mathrm{NO}_{3}\right)\right]\left(\mathrm{NO}_{3}\right)_{2} \cdot 2 \mathrm{H}_{2} \mathrm{O}\right\}$ & 2945 & 1616 & 1560 & 1435 & 1315 & 1040 & 120 & 1375 & 3210 \\
\hline
\end{tabular}

${ }^{*} \Delta v=v 1-v 5$.

Electronic spectra. The electronic spectra of the complexes were recorded in freshly prepared dmf solutions. The spectra are virtually identical for all the complexes. A fairly symmetrical new band is observed for each complex at $c a .407 \mathrm{~nm}$. This band disappears when the complex is treated with $\mathrm{NaBH}_{4}$ in order to reduce the $\mathrm{C}=\mathrm{N}$ group in saturated moiety. Therefore the absorption at $c a .407 \mathrm{~nm}$ must be associated with the $\mathrm{C}=\mathrm{N}$ chromophore coordinated to the metal ion through the nitrogen atom. The UV spectra of the complexes provided also further information. An intense band was also observed at $c a .335 \mathrm{~nm}$, in some of the complexes. It was absent both for the free ligand and the nitrate salts. This band is assigned to charge transfer between the coordinated ligand and the metal ion. The electronic spectral data are summarized in Table 3.

Magnetic moments. The magnetic moment of the lanthanide(III) complexes are summarized in Table 3. The values show little deviation from the theoretical values predicted for the trivalent lanthanide ions. This fact suggests that the $4 \mathrm{f}$ electrons do not participate in the bond formation of the metal to the ligand [23].

Molar conductivities. The molar conductivities of the complexes were measured in dimethyl formamide (dmf) for freshly prepared solutions and after standing for two weeks. The conductivities increased very slightly with time in $\mathrm{dmf}$ for all the complexes except for Sm. This is probably due to the very slow replacement of the coordinated nitrate by the solvent molecules. The values of these conductance are in the range $27-70 \mathrm{Ohm}^{-1} \mathrm{~cm}^{2} \mathrm{~mol}^{-1}$ in $\mathrm{dmf}$ and are less than those reported for 1:1 electrolytes in this solvent [24]. This is indicative that these complexes dissociate very slighly in this solvent. In contrast to the infrared spectra where the compounds were formulated as 1:2 electrolytes with two nitrates as counter ions, the molar conductivities show that all the nitrates ions are present in the coordination sphere in solution. This suggests

Bull. Chem. Soc. Ethiop. 2003, 17(1) 
that the behaviors of the complexes in solid state are different from the behaviors when the compounds are in dmf the solution.

Table 3. Electronic data, magnetic moments and conductance data of the complexes.

\begin{tabular}{|c|c|c|c|c|}
\hline \multirow[b]{2}{*}{ Complexes } & \multirow[b]{2}{*}{ UV bands } & \multicolumn{2}{|c|}{$\Lambda / \Omega^{-1} \mathrm{~cm}^{2} \mathrm{~mol}^{-1}$} & \multirow[b]{2}{*}{$\mu / \mu_{\mathrm{B}}$} \\
\hline & & fresh & $\begin{array}{l}2 \text { weeks } \\
\text { after }\end{array}$ & \\
\hline $\mathrm{C}_{22} \mathrm{H}_{16} \mathrm{~N}_{4} \mathrm{O}_{5} \mathrm{Cl} .2 \mathrm{H}_{2} \mathrm{O}$ & $270,320,345,365,420,440,475$ & - & - & - \\
\hline$\left\{\left[\mathrm{La}_{2}\left(\mathrm{H}_{4} \mathrm{~L}\right)_{3}\left(\mathrm{NO}_{3}\right)\right]\left(\mathrm{NO}_{3}\right)_{2} \cdot 6 \mathrm{H}_{2} \mathrm{O}\right\}$ & $270,320,350 \mathrm{sh}, 360,375 \mathrm{sh}$ & 54 & 56 & Diam. \\
\hline$\left\{\left[\mathrm{Ce}_{2}\left(\mathrm{H}_{4} \mathrm{~L}\right)_{3}\left(\mathrm{NO}_{3}\right)\right]\left(\mathrm{NO}_{3}\right)_{2} .7 \mathrm{H}_{2} \mathrm{O}\right\}$ & $267,305 \mathrm{sh}, 320,405$ & 64 & 70 & 3.41 \\
\hline$\left\{\left[\mathrm{Pr}_{2}\left(\mathrm{H}_{4} \mathrm{~L}\right)_{3}\left(\mathrm{NO}_{3}\right)\right]\left(\mathrm{NO}_{3}\right)_{2} .5 \mathrm{H}_{2} \mathrm{O}\right\}$ & $265,305 \mathrm{sh}, 335,353,405,425 \mathrm{sh}$ & 57 & 62 & 5.41 \\
\hline$\left\{\left[\mathrm{Nd}_{2}\left(\mathrm{H}_{4} \mathrm{~L}\right)_{3}\left(\mathrm{NO}_{3}\right)\right]\left(\mathrm{NO}_{3}\right)_{2} .5 \mathrm{H}_{2} \mathrm{O}\right\}$ & $265,335,407,417 \mathrm{sh}$ & 55 & 60 & 5.38 \\
\hline$\left\{\left[\mathrm{Sm}_{2}\left(\mathrm{H}_{4} \mathrm{~L}\right)_{3}\left(\mathrm{NO}_{3}\right)\right]\left(\mathrm{NO}_{3}\right)_{2} .4 \mathrm{H}_{2} \mathrm{O}\right\}$ & $265,323 \mathrm{sh}, 335,407,418 \mathrm{sh}$ & 52 & 52 & 2.22 \\
\hline$\left\{\left[\mathrm{Gd}_{2}\left(\mathrm{H}_{4} \mathrm{~L}\right)_{3}\left(\mathrm{NO}_{3}\right)\right]\left(\mathrm{NO}_{3}\right)_{2} \cdot 6 \mathrm{H}_{2} \mathrm{O}\right\}$ & $265,333,345 \mathrm{sh}, 410,430 \mathrm{sh}$ & 57 & 62 & 13.13 \\
\hline$\left\{\left[\mathrm{Dy}_{2}\left(\mathrm{H}_{4} \mathrm{~L}\right)_{3}\left(\mathrm{NO}_{3}\right)\right]\left(\mathrm{NO}_{3}\right)_{2} .5 \mathrm{H}_{2} \mathrm{O}\right\}$ & $265,330,340,353,405,418 \mathrm{sh}$ & 49 & 58 & 18.08 \\
\hline$\left\{\left[\mathrm{Er}_{2}\left(\mathrm{H}_{4} \mathrm{~L}\right)_{3}\left(\mathrm{NO}_{3}\right)\right]\left(\mathrm{NO}_{3}\right)_{2} \cdot 4 \mathrm{H}_{2} \mathrm{O}\right\}$ & $265,323 \mathrm{sh}, 340,352,407,425 \mathrm{sh}$ & 27 & 29 & 16.38 \\
\hline$\left\{\left[\mathrm{Yb}_{2}\left(\mathrm{H}_{4} \mathrm{~L}\right)_{3}\left(\mathrm{NO}_{3}\right)\right]\left(\mathrm{NO}_{3}\right)_{2} .4 \mathrm{H}_{2} \mathrm{O}\right\}$ & $263,310 \mathrm{sh}, 335,350,405,420 \mathrm{sh}$ & 53 & 61 & 7.44 \\
\hline$\left\{\left[\mathrm{Y}_{2}\left(\mathrm{H}_{4} \mathrm{~L}\right)_{3}\left(\mathrm{NO}_{3}\right)\right]\left(\mathrm{NO}_{3}\right)_{2} \cdot 2 \mathrm{H}_{2} \mathrm{O}\right\}$ & $340,353 \mathrm{sh}, 405,418 \mathrm{sh}$ & 45 & 54 & Diam. \\
\hline
\end{tabular}

\section{CONCLUSION}

The electrolytic conductivity data indicate that the lanthanide nitrates complexes do not behave as electrolytes in dimethylformamide. The infrared spectra indicate that not all the nitrate groups are involved in the coordination. IR data reveal the presence of bidentate and ionic nitrate in these complexes. The organic ligand acts as a pentadentate ligand via the anionic oxygen of the one 4-chlorophenol group, the oxygen of the two amide functions and the nitrogen of the two azomethine groups. Three molecules of the macro acyclic ligand with two similar metal-binding sites sharing the phenolic oxygen atom act with two lanthanides ions. This suggests that, in these complexes each $\mathrm{Ln}$ (III) ion is surrounded by seven oxygen atoms and three nitrogen atoms producing a ten coordination number complex (Figure 1).

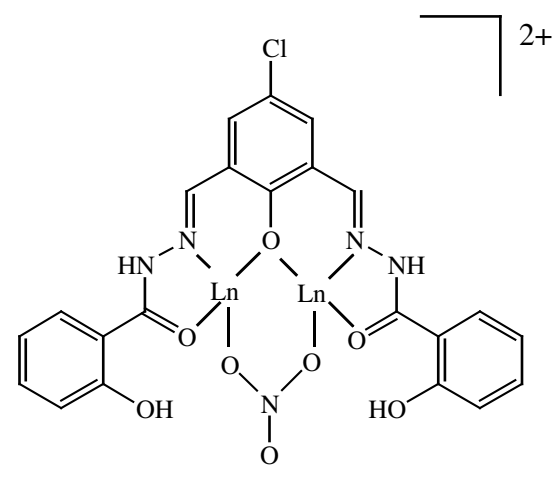

(a) 


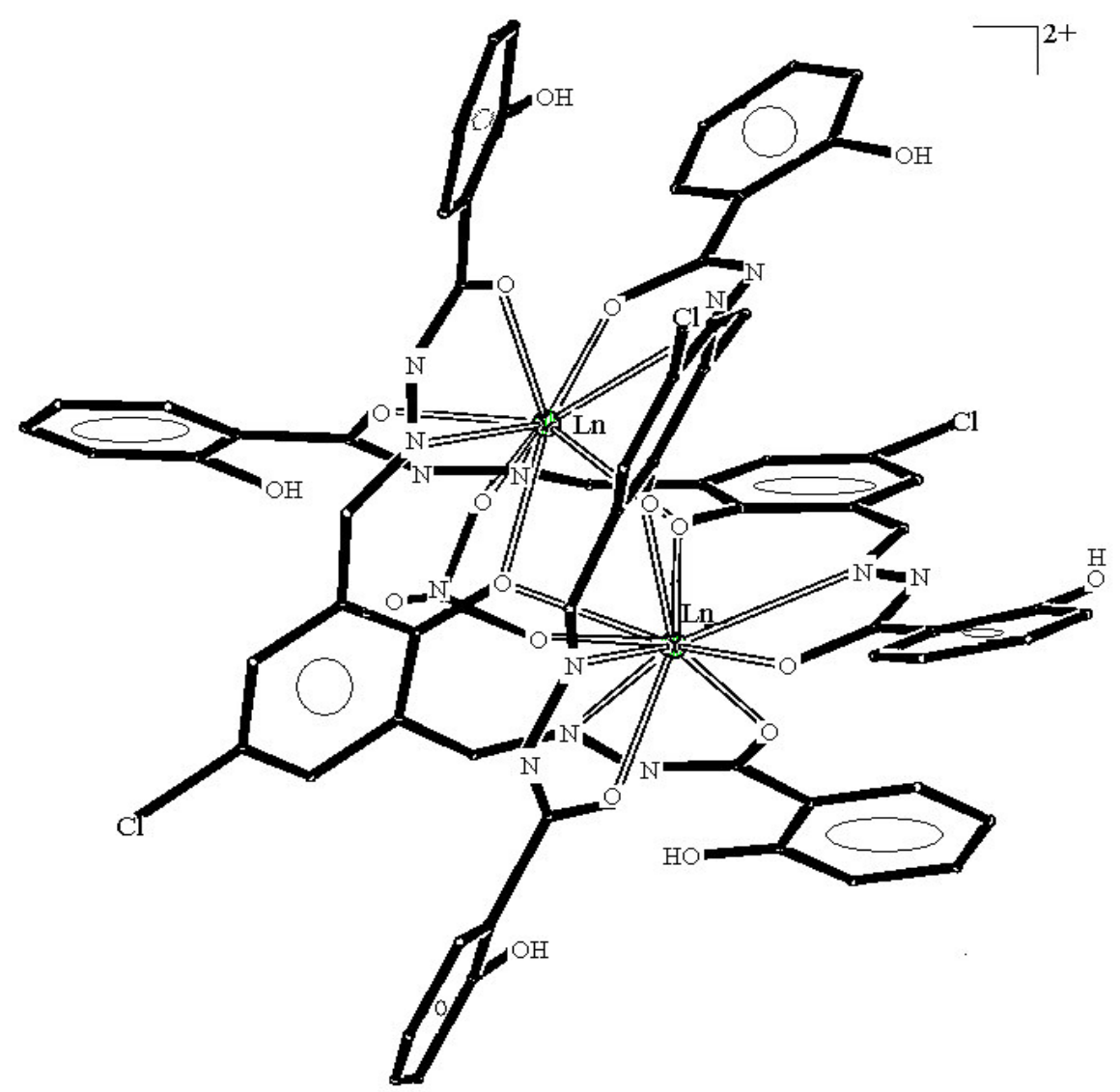

(b)

Figure 1. Schematic proposed structure: (a) two monodeprotonated ligand $\left(\mathrm{H}_{4} \mathrm{~L}\right)$ were omitted for clarity, and (b) structure with all the three monoanionic Schiff base ligand.

\section{ACKNOWLEDGMENT}

The authors thank the Third World Academy of Science (TWAS) for financial support under the research grant $\mathrm{N}^{\circ}$ 97-034 $\mathrm{RG} / \mathrm{CHE} / \mathrm{AF} / \mathrm{AC}$.

\section{REFERENCES}

1. Dietrich, B.; Viout, P.; Lehn, J.-M. Macrocyclic Chemistry, VCH Publishers: Veinheim; 1993; ch. 3 and references therein.

2. Aruna, V.A.J.; Vedhamonickom, A. J. Chem. Soc. Dalton. Trans. 1996, 1867.

3. Vallarino, L.M. J. Less-Common Metals 1989, 149, 121.

Bull. Chem. Soc. Ethiop. 2003, 17(1) 
4. Costes, J.P.; Dupuis, A.; Laurent J.-P. Inorg. Chim. Acta 1998, 268, 125.

5. Archer, R.D.; Thompson, L.C. Inorg.Chem. 1998, 37, 2089.

6. Xie, W.; Heeg, M.J.; Wang, P.G.; Inorg. Chem. 1999, 38, 2541.

7. Morrow, J.R.; Buttrey, L.A.; Shelton, V.M.; Berbark, K.A. J. Am. Chem. Soc. 1992, 114, 1903.

8. Jurisson, S.; Berning, D.; Jia, W.; Ma, D. Chem. Rev. 1993, 93, 1137.

9. Evans, C.H. Biochemistry of the Lanthanides, Plenum: New York; 1990.

10. Bunzhi, J.-C.G. in Lanthanides Probes in Life, Medical and Environmental Sciences, Choppin, G.R.; Bunzhi, J.-C.G. (Eds.); Elsevier: Amsterdam; 1989; ch 7.

11. Guerriero, P.; Casellato, U.; Tamburini, S.; Vigato, P.A.; Graziani, R. Inorg. Chim. Acta 1987, $129,127$.

12. Abib, K.K.; Fenton, D.E.; Casellato, U.; Vigato, P.A.; Graziani, R. J. Chem. Soc. Dalton Trans. 1984, 351.

13. Afshar, S.; Bullock, I.I. Inorg. Chim. Acta 1980, 38, 145.

14. Terzis, A.; Mentzafos, D.; Tajmir-Riahi, H.A. Inorg. Chim. Acta 1984, 84, 187.

15. Gaye, M.; Sall, A.S. Bull. Chem. Soc. Ethiop. 1995, 9, 31.

16. Gaye, M.; Sall, A.S.; Sarr, O.; Russo, U.; Vidalli, M. Polyhedron 1995, 4, 655.

17. Sall, A.S.; Gaye, M.; Russo, U.; di Noto, V. J. Chem. Res. S 1995, 266; J. Chem. Res. M 1995, 1657.

18. Sall, A.S.; Gaye, M.; Sarr, O.; Caneschi, A.; di Noto, V.; Vidalli, M. J. Chem. Res. S 1997, 347.

20. Alyea, E.C.; Malek, A.; Vougioukas, A.E. Can. J. Chem. 1982, 60, 667.

19. Carnall, W.T.; Siegel, S.; Ferrano, J.R.; Tani, B.; Gebert, E. Inorg. Chem. 1973, 12, 560.

21. Ferrano, J.R. J. Mol. Spectra 1960, 4, 99.

22. Suresh, K.D.; Alexander, V. Inorg. Chim. Acta 1995, $238,63$.

23. Van Vleck, J.H.; Frank, A. Phys. Rev. 1929, 34, 1494, 1625.

24. Geary, W.J. Coord. Chem. Rev. 1971, 7, 81. 